\title{
The New World Order, Human Rights and Extradition Laws in Africa: Impacts and Prospects
}

\author{
Lucas Nduka Oluka $^{1^{*}} \quad$ C. Ailende Ativie ${ }^{2} \quad$ Okwanuzor Mwaamaka Okuguni $^{3}$ \\ 1.Department of Political Science, Novena University, Ogume, Delta State, Nigeria \\ 2.Department of Political Science, Novena University, Ogume, Delta State, Nigeria \\ 3.The Law School, Robert Gordon University, Aberdeen, Scotland, United Kingdom
}

\begin{abstract}
Before the emergence of the New World Order (NWO), the atrocities, crimes and offences committed by ignoble African tyrants, dictators, rulers and unwieldy but powerful individuals such as Idi Amin Dada of Uganda, Omar al-Bashir of Sudan, Hussein Habre of Chad Republic, and a no-less despotic others were beforehand treated with kids gloves, while the actors were considered to be local in character. But today, these offences have morally and legally become unacceptable before the larger world. This study, thus, argued that the change in perception in what constitutes a crime and what does not has ushered in tremendous changes in action and attitude towards all forms of offences. This has brought to the fore the need for one country to collaborate with other countries of the world, to achieve crime control, as well as strengthen the need for the exchange of criminals who may have committed offences such as war crimes, genocide, terrorism, money laundering, drug and human trafficking, etc., and to bring to book such crime perpetuators who may be on the run or are on the wanted list. The inquiry also argued that the change in perception of what constitutes a crime in Africa has led to a decrease in the exercise of impunity and uncontrollable abuses of human rights by the dishonourable men of power. More fundamentally is the increase in extradition arrangements or treaties in Africa. The research, consequently, is aimed at examining various extradition cases involving African leaders and individuals who have, in one way or the other, committed or allegedly committed extraditable offences in recent times. Equally is the emphasis placed on the need for increase in extradition accords and prospects in Africa. To achieve its aim, therefore, the study adopted qualitative and explorative methods of analysis which means that the secondary source of data collection such as textbooks, journal articles and official documents were employed considering the nature and scope of the research. Anchoring our analysis on "'System theory", the investigation proceeded to suggest that the government of the states of Africa should continue to cooperate with one another as with other nations of the world so as to sustain the achievement so far recorded in the area of crime control through extradition agreements.
\end{abstract}

Keywords: New World Order, New World System, Cold War, Extradition treaties, Agreements, Fugitive offenders , Criminals, Tyrants, Dictators.

DOI: $10.7176 / J L P G / 82-14$

\subsection{Introduction}

The present world system which is free from all forms of antagonism associated with the Cold War era ushered in a lot of changes and perceptions of what constitutes a crime against the provisions of the international humanitarian law. This also prompted the United Nations Security Council (UNSC) on Human Rights to establish international criminal courts such as the International Criminal Tribunal for Rwanda (ICTR) created in 1993 and the Special Court for Sierra Leone established in 2002 under the supervision of the International Criminal Court (ICC). The ICC was founded on 1 July 2002 under the Statute of Rome and has the jurisdiction to prosecute individuals for the international crimes of genocide, war crimes and other forms of crime against humanity. Omar al-Bashir of Sudan, Hussein Habre of Chad Republic, Yorodia Ndombasi of the Democratic Republic of Congo (DRC), Charles Taylor of Liberia, among others, were accused of committing atrocities against their people during wars in their respective states and were found culpable in one way or the other by the ICC (Onyekpe, 2001; Prevent Genocide International, 2001; Ezeibe, 2011: 3). This has equally permitted the progressive realisation of the Sections of Article 1 of the UN Charter which deals specifically with the achievement of international, regional and sub regional cooperation in resolving problems associated with the economic, social and cultural crises, and crime control through bilateral and multilateral agreements such as extradition treaties or statutes (see Article 1 of the UN Convention on Human Rights, 1994). The ethnic cleansing in Yugoslavia in 1991 and 2001 which led to the breakup of the Yugoslav states and the constitution of independent states; the April 7, 1994 to July 1994 genocide war in Rwanda which was a different kind of violence altogether from what had happened before; the upsurge in crime rates such as trafficking in humans and in narcotic substances; as well as the rise in insurgency and terrorism parts of the world also did prompt the UN General Assembly and the Security Council to re-emphasise the need for implementation of international extradition laws and other sundry laws of nations, to defeat all forms of aggressions and impunity, and restore maximum peace and security in Africa (Robert H. Jackson Center, 2001; International Center for Transitional Justice, 2009).

Apparently, the emergence of a new world system changed the perception of what constitutes crime in Africa 
and increased extradition agreements among states and the number of individuals and leaders indicted for different offences in recent time. Examples abound in the indictment of 36 Africans including Charles Taylor of Liberia, Laurent Gbagbo of Ivory Coast, Muammar Gaddafi of Libya, President Uhuru Kenyatta of Kenya, Deputy President William Ruto of Kenya, President Omar al-Bashir of Sudan, Jean-Pierre of Democratic Republic of Congo (DRC), among others. These leaders, out of power and some still serving were indicted by the International Court of Justice (ICC) for different offences (Roth, 2014; Motsoko, 2015). In other words, the issue of extradition has gone beyond local or national legal practice. It is now a collective general responsibility and concern of states towards the achievement of international human rights. Cases of impunity and war crimes that were never considered by an international judicial body before the emergence of the present world system have now become a matter of general concern of all. This has necessitated the need for exchange of tyrannical rulers and individuals who have committed extradition offences such as murder, attempted murder, genocide, embezzlement of public funds, piracy, kidnapping, abduction, trafficking in narcotics and in humans, false imprisonment, arson, rape, bigamy, terrorism, etc. However, the effect of the present world order has also necessitated the increase in human rights adoption in Africa, as well as in extradition cases and the treaties signed by countries.

\subsection{Statement of the Problem}

The paradigm shift from the old world system, characterized by the ideological antagonism of the cold war between the United States and the Soviet Union, and their allies, ushered in a new world system, characterized by unacceptable violations of human rights, impunity and dictatorship. The new paradigm also has enshrined democratic principles in Africa, and has prompted the UN to take certain measures aimed to curtail crimes against humanity in warfare, where they occur, and in other forms of unrest across states in Africa such as the 1994 genocidal war in Rwanda, the civil war in Sierra Leone in the 1990s, and in Liberia, also in the 1990s (Rebane, 1995; International Center for Transitional Justice, 2009). Equally, the new order has changed the perception of what constitutes a crime and what does not. The consequence of this is the rise of the UN body, with several resolutions, to control crimes perpetrated against humanity and the extradition of wanted criminals and fugitive offenders from other lands. The result is the high profile extradition cases in the history of Africa such as the extradition of Obed Rudidabd from Kenya to Arusha in Tanzania, in the 1990s; the extraction of Yorodia Ndombasi from the Democratic Republic of Congo (DRC) to Belgium in 2000, on charges of offences constituting grave breaches of the Geneva Convention; and the most celebrated extradition case of Charles Taylor of Liberia in the Netherlands on June 15, 2006 (Prevent Genocides International, 2001; Ezeibe, 2011; Boston College, 2015). In spite the role that the new world system played in the change of perception in what constitutes a crime and otherwise; in the functional implementation of extradition treaties; and in the extradition and prosecution of African leaders and individuals alleged to have committed atrocities against humanity and other forms of extraditable offences, it is obvious that extradition agreements and cases in Africa are, indeed, bedeviled by several problems. The problems include needless granting of asylum to reckless leaders by some states, granting of presidential pardons to political allies, and unnecessary delay occasioned by bureaucracy and differences in values and judicial systems. Issues of human rights pursued by all states in Africa as emphasised in the Charter of the UN and the African Union (AU), which is considered sacrosanct in implementation, in respect of extradition, has also encumbered extradition processes in Africa. This study, therefore, sought to examine the impact of the present world order, in the achievement of extradition agreements or treaties, exchange and prosecution of dictators and tyrants, erstwhile leaders and individuals who have abused human rights and committed all other forms of extraditable offences in Africa. The investigation also sought to examine the prospects of extradition treaties in Africa.

\subsection{Objectives of the Study}

The main objective of this study is to examine the impact of the new world order in sustaining the provisions of international human rights. As well, it is to examine the achievements recorded in the exchange and prosecution of alleged criminals and fugitive offenders occasioned by increase in extradition treaties in Africa. While the specific objectives of the study are to:

(i) Examine the link between the new world order and increase in extradition treaties and cases in contemporary African states,

(ii) Examine the extent to which UN's implementation of extradition laws affected that of African states, and

(iii) Proffer solution to the problems associated with extradition cases in Africa.

\subsection{Research Questions}

To give direction to this study the following research questions were raised:

(i) What is the link between the new world order and increase in Extradition treaties in contemporary African states? 
(ii) To what extent have the UN's implementation of extradition laws affected extradition laws in Africa?

(iii) What are the possible solutions to the problems associated with the implementation of extradition treaties in Africa?

\subsection{Research Method}

The study employed explorative and qualitative research method to examine the link between the present world order and increase in extradition agreement and prosecution of leaders and individuals who were culpable of extraditable offences in Africa. In essence the data used in this study were collected from secondary source. Secondary source of data collection refers to materials that were not originally from the researchers but from already existing literature such as textbooks, journal publications, scholarly articles, internet sources and official documents.

\subsection{Theoretical Framework}

This study adopted the "System theory" which deals with the notion of a system as a set of interrelated subsystems. Beginning from Ludivig Von Bertalanffy, who was believed to be the originator of the system theory, scholars like Karl Deutch, Morton Kaplan, David Singer, Charles McClelland and Kenneth Boulding, in the 1930s, also contributed to the development of the theory (see Akwem, 2011). According to Mahajan (1988: 32) in Oromaregheke and Oluka (2016: 22), modern day contributors to the system theory include David Easton and Talcott Parson. Each of these contributors has had to modify the theory, to give it a meaning that is suitable to the function of the theory. By and large, system theory captures the idea that the behaviour of the whole is greater than the sum of its parts (Ansari, 2004). The term "system" in system theory is of Latin origin, "systema", which simply means "to bring together". In other words, it is a set of separate components that are interrelated with one another to form a whole and to function as a whole. In this respect, states are considered as subsystems of a whole, i.e., the global system. Although interactions between and among states in the international system have varied over time, particularly after the collapse of the cold war era. By the late $20^{\text {th }}$ and $21^{\text {st }}$ Centuries, the relations between states have become more global in scope and unprecedented in their number and in the types of actors involved. It expanded not only to include the greater movement of people but also of trade, investment, ideas, information and crime control, all of which were shaped by technological advancement (Akwen, 2011). This has also expanded the notion of what constitutes a crime and what does not; what is perceived to fall short of the Universal Declaration on Human Rights and the significance of which is the idea of collective responsibility to control all forms of crime through extradition treaties or agreements. This implies that the change in our perception of what is a crime and what is not a crime is not only regionalised but also has been globalised since the states in Africa are now interconnected with other states in the world. The interconnectedness of states in the international system has provided fugitive offenders and criminals with no "safe haven".

\subsection{Literature Review}

\subsubsection{The New World Order (NWO): Conceptual Explanation}

Without a doubt, the end of the Cold War and the dismantling of the old world order prompted a new world order which was characterised by the realisation of Article 1 of the UN Charter of 1994. This article deals with the probable means by which international cooperation can be achieved in resolving worldwide problems associated with economic, social and cultural downturns and human rights as stated earlier in this study (see the UN Convention on Human Rights, 1994). Despite the difficulties encountered in determining what constitutes the new world system, there is a consensus belief that the new system ushered in a tremendous change of attitudes and perceptions of what constitute a crime against humanity particularly in Africa and in the world at large. In essence, the term has been used to refer to any event in the history of the world which reflects a dramatic change in world politics and that has attempted to balance the powers of states in the global system. As diverse as its interpretations may be, the new world system is primarily linked with the ideological notion of a global governance and the collective effort of states to identify, understand and address global problems that are beyond the capacity of individual states to resolve (Martins, 2003).

The term, new world system, in its current state, was popularised, in its western usage, by Woodrow Wilson, in his fourteen-point speech before a joint meeting of the Congress of the League of Nations (LNs), held on 8 January 1918. In recent times, the term was associated with the end of the Cold War (Martins, 2003). President Mikhail Gorbachev of the defunct Soviet Union Socialist Republic (USSR) and George W. H. Bush, former president of the United States of America, used the term to define the nature of the post-cold war era and the spirit of power operation envisaged for the global system. In 1991, President Bush used the term to refer to the state of the world after the end of the cold war and the collapse of the Soviet Union (Gorbachev, 1988; Brent, 1991). In June 1990, this notion was re-emphasised by Gorbachev when he stated that: 
order (Gorbachev, 1990).

To come out from the US-Soviet antagonism created by the cold war, there must be a new world system free from the US-Soviet antagonism. To this end, Gaddis (1991) corroborated this statement when he opined that the new world order is a period characterised by unchallenged American primacy, increasing integration, resurgent nationalism and religiosity, a diffusion of security threats and collective security. He argued that this period is associated with a lot of changes in human existence which involves changes in communication pattern, in international economic system, as well as in the nature of security threats, and a rapid spread of new ideas that will prevent national isolationism (Gaddis, 1991). For Strobe Talbolt (1991), the new world order is the aftermath of the Persian Gulf War in which the UN took a step towards redefining its role to take proper account of both interstate relations and events.

On November 13, 2000, former British Prime Minister Tony Blair, British envoy to the Middle East, agreed with the facts of the new world order when he said "like it or not", it is a new consensus; it presumes a shared agenda and a global partnership to do it (BBC News, 2001; BBC News, 2002). In another perspective, Gordon Brown, also a former United Kingdom Prime Minister, in a 2008 speech in New Delhi, expressed concern over the rise of Asia, global warming and finance, and noted that the new world should incorporate a better representation of the biggest shift in the balance of economic power in the world, between the UK and Asia. He called for the revamping of post-war global institutions including the World Bank, G8 and International Monetary Fund (IMF), and suggested that a 100 million US dollar annual budget to be made available, to set up a rapid reaction force, to intervene in failed states including Africa (Grice, 2008).

Dr. Ahmadinejad Mohammad, former Iranian president, in his speech about the present world order, said the era should be one where tyranny should come to a dead end. This, he said, should be based on achieving world peace, global collective security, reciprocity and justice with full support from Iran. This view was supported by Abdullah Gul, former Turkish Prime Minister (from 2007-2014). Gul had suggested that instead of unilateral actions, nation-states should act collectively and make common decisions, and have consultations with the world so as to achieve a better and practicable new world order (Kinze, 2008; Almadinejad, 2012; Press TV, 2012).

From the plethora of descriptions above, it is obvious that the present world system is free from the ideological antagonism of the cold war which was overrun by the activities of tyrants, dictators and rascals on the part of some African leaders and dissident individuals. Besides the change in perception of "what constitutes a crime and what does not", so presented by the emergence of the present world system, the era shifted its broader objective to the protection of human rights and subscribed to the principles of the United Nations Universal Declaration On Human Rights (UN UDHR) proclamation made by the UN General Assembly in Paris on 10 December 1948 (see General Assembly Resolution 217A). The proclamation includes freedom from slavery and servitude; freedom from torture or cruelty, inhuman or degrading treatment or punishment; freedom from arbitrary interference with privacy, family, home or correspondence; freedom of movement; and freedom to seek asylum. Furthermore, the resolution guaranteed the right to a nationality; freedom of thought, conscience and religion, opinion and expression; and the right to work, to equal pay for equal work, to form and join trade unions (UDHR, 1948). This informed the UN General Assembly and the Security Council's decision to prosecute those who committed atrocities against humanity and those involved in other forms of crimes and extraditable offences, particularly in Africa.

For the purpose of this research, we posit that the concept of new world order is the era of global economic, social, cultural and political cooperation, and crime management; to be able to combat with all forms of extraditable offences such as murder, genocide, money laundering, and other forms of financial crimes; human and drug trafficking, insurgency and terrorism, among others.

\subsection{Extradition: Conceptual Explanation}

It is important to note that the present world system also ushered in implosive trends in agreements concerning extradition treaties and exchange of wanted criminals. Although in classical tradition, nation-states recognised the need for cooperation in crime control and in the exchange of wanted individuals through diplomatic means or through negotiation and reciprocity, modern trend, however, demands that an individual should not be extradited in the absence of a treaty of extradition between the parties concerned. In line with this notion, Bassiouni (2001), noted that the origin of extradition was traced to classical civilisations such as the Egyptian, Chinese, Chaldean and the Assyro-Babylonian cultures. He also noted that the earliest forms of what seems to be extradition agreement was found in a political document containing a peace treaty between Ramses II, the Pharaoh of Egypt, and the Hittites King, Hattusli III, in 1280 B.C. A similar provision of such arrangement was seen in Western Europe in 1174 AD, between Henry II of England and William the Lion, King of Scotland (Rebane, 1995).

This shows that extradition is an ancient tradition because the surrender of wanted individuals was an unusual remedy and it was extra-traditional to exchange wanted individuals who have committed unacceptable offences. There is also a consensus belief that the term extradition was derived from a Latin word extradere which means forceful return of an individual from his state of asylum to the requesting state (Bassiouni, 2001: 31). This notion was what informed the evolvement of a plethora of descriptions for the concept. For Von Glahn (1970), in modern 
times, international law knows no rights to extradite apart from treaties. In other words, a state may decide to voluntarily surrender a fugitive for justice but the legal right to demand for such surrender can only be real where there is an existing agreement in the form of treaty or treaties of extradition (Glahn, 1970). Cheriff Bassiouni (1974) opines that extradition involves delivering an individual, usually a fugitive offender, for justice by one state usually known as the requested or asylum state, to another known as the requesting or extradition-seeking state. To him, extradition treaties address the attempts to resolve crimes committed by an individual in one country, who has taken refuge in another (Bassiouni, 1996).

The United States official opinion on extradition denies the existence of any authority to extradite a fugitive offender in the absence of a treaty. It defines extradition as the surrender from one state to another of an individual accused or already convicted of an offence outside his own territory and within the territorial jurisdiction of another state which is competent to demand the surrender of the individual, as well as to try and punish the offender (United States Code [U.S.C.] 18 3181). McHam (1998) had observed that a few of the prominent extradition scholars and authors used the US Statutory provisions and definition of extradition to establish the foundations for their extradition research while some created their own definition and what constitutes extradition offence and what does not. For example, Sunnil (2000) defined extradition as the formal process by which an individual known as the "extraditee" is surrendered from the state of asylum where he is located, to the requesting or claimant state in order to face prosecution or if already convicted to serve a sentence. Abegunde (2014) posits that extradition is the surrender of a criminal by one sovereign authority to another. He also sees it as the process of returning someone accused of a crime by a different legal authority for trial or punishment.

In the same manner, Sadoff (2016) opines that extradition is the act by one jurisdiction of delivering a person who has been accused of committing a crime or has been convicted of a crime in another jurisdiction into the custody of the law enforcement agency of the other jurisdiction. He also sees extradition as a "cooperative law enforcement process between the two contracting parties or jurisdictions, and that which depends on the agreements reached by the two parties. Apart from the legal aspects of the process of extradition in recent times, extradition also involves the physical transfer of the custody of the person being extradited to the legal authority of the requesting state (Sadoff, 2016). Robyn (2007), in Adishi and Oluka (2018), observed that the decision of whether or not to extradite an offender and the method to be employed in the process of extradition lies in the hands of the requested or asylum state, and when extradition eventually takes place, the law provides for the protection of the fundamental rights of the extraditee as prescribed by the UN Universal Declaration on Human Rights of Paris (1948). In other words, in the absence of an extradition treaty or statute, a fugitive offender cannot be extradited nor can his surrender be requested. In the absence of such arrangement, the grant of extradition should depend on reciprocity or courtesy (Abegunde, 2014).

\subsubsection{Possible Exceptions and Limitations to Extradition Laws}

(a) Double/Dual Criminality principle of extradition: The double or dual criminality principle states that unless the offence alleged to have been committed by an individual constitutes offence in both the extradition-seeking and the asylum states, the individual should not be extradited. This is a possible exception or obstacle to extradition. It means that extradition would not be granted to the seeking state unless the offence committed is contained in the domestic or national laws of both the asylum and extradition-seeking states. This is a plausible indication that double criminality is a requirement in extradition procedures since extradition is only allowed for offences alleged as crimes in both jurisdictions. Its origin was traced to the United States' extradition jurisprudence. It also has its root in the Jay Treaty of 1794 which involved the United States and Great Britain. The standardisation of double criminality began with a British statute and today, it is a requirement in the extradition law of many countries including those of Africa (Jonathan, 1992).

A suspect, therefore, cannot be extradited from one country to stand trial for breaking another country's law unless the offence committed is regarded as an offence in both countries. For example, if Country " $A$ " has no laws against blasphemy and Country "B" also has the same law; double criminality could prevent a suspect to be extradited from country "A" to country "B" (see US Legal Definition, 1997-2016). In essence, double criminality can only be applied when the offence committed by the offender concerns both state parties. This implies that the offence which would give rise to extradition must be regarded as a crime under the national laws of both contracting parties and must be contained in a treaty concerning extradition between them (Shaw, 1997: 60). In other worlds, there must be a nexus between the interests of both parties in the granting or denial of extradition (Oluka, 2018: 65). The observation of the rules of extradition has guided African states in the area of according respect to each other's sovereignty and in the human rights of extraditees, in the course of demanding for the exchange or transfer of wanted criminals.

(b) Specialty Principle: Extradition laws also permit specialty principle of extradition which states that extraditees should not be prosecuted for crimes other than those specified in the extradition request (Rebane, 1995). But this constitutes an impediment to extradition laws since the extraditing country under this principle is prevented from presenting an individual or an offender for crime other than those specified in the extradition request. The alleged offender may not even be tried for a lesser offence if it is not contained in the extradition request. 
(c) Extra-Territoriality: This is the right of states to control activities within their national jurisdiction or territory. This, according to Rebane (1996), is the principal historical limitation to extradition laws since the respect for the territorial sovereignty of states forms the basic tenet of international law and must be respected. When a state employs a unilateral method to capture an offender, international pressures may force that state to retrace its steps. The state may also suffer to be fined and reprimanded (Rebane, 1996).

\subsection{Empirical Review}

\subsubsection{The New World Order and Increase in Extradition Cases in Africa}

It is quite evident that the present world system promoted significant increase of bilateral and multilateral treaty arrangements in Africa. It has also promoted internal independence which empowers states to exercise absolute and supreme authority over all persons and things found within their territories, as well as the power to exercise jurisdictional control within their domain. This independence does not give states unlimited liberty to do what they wish without restriction and respect for human rights and dignity since extradition issues are no longer national issues but the general concern of all. The Federal Republic of Nigeria has several treaties of extradition with other countries both within and outside the continent of Africa. On 30 November 2002, the government of the Federal Republic of Nigeria rectified its extradition treaty with the Republic of South Africa (NLIP, 2002). In recent years, the government of Nigeria has also strengthened its legal framework for extradition to include the establishment of a Central Authority Unit (CAU) in 2012, to coordinate extradition and mutual legal assistance matters; amend the Extradition Act of 1966 by the Extradition Act (Modification) Order 2014, and the Issuance of the Extradition Act (Proceedings) Rules 2015 by the Chief Judge of the Federal High Court, etc., in order to adopt the contemporary trend in extradition processes (UN Office on Drug and Crime, UNODC, Abuja 2016).

More of the extradition arrangement within and outside the continent was seen in the 1984 extradition treaty between the Republics of Benin, Ghana and Togo, and Nigeria purposely signed to preserve peace and security among the state parties, and to fight crime in all its forms by facilitating the apprehension and trial of fugitive offenders from the territory of any of the contracting parties to the territory of each other. In 2005, the government of South Africa signed extradition treaty with the government of Nigeria, commonly refers to as 'Ratification and Enforcement Act of 2005" purposely to guarantee both parties the obligation to extradite fugitive offenders on request (UNODS, 2016).

The 1960 Independence agreement between the government of Nigeria and those of United Kingdom and Northern Ireland, which guaranteed the right of inheritance of international rights and obligations, ratified under Volume 384 of 1961 of the United Nations Treaty Series, is also a pertinent example of the treaty agreement in Africa. In recent times, the United Kingdom (UK) government and the government of Nigeria signed an agreement for the purpose of transferring sentenced persons to serve punishments. This agreement is today known and referred to as the "Agreement between the Government of the United Kingdom of Great Britain \& Northern Ireland and the Government of the Federal Republic of Nigeria on the transfer of Sentenced Persons, 2014"'. The treaty came into force on 29 September 2014. There was also the extradition treaty between the State of the United Arab Emirates (UAE) and the Federal Republic of Nigeria signed in 2016 (UNODC, 2016), and others.

However, the significance of the increase in awareness of what constitutes an offence and what does not, and the extradition treaty pact in the continent is characterised by zero tolerance for impunity, dictatorship, genocide, war crimes, terrorism, financial fraud and money laundering, as well as human and drug trafficking across national boundaries. This resulted in high profile cases and requests such as the extradition requests of Mr. Hussein Habre, ex-president of Chad Republic, who was accused of killing and torturing tens of thousands of his opponents between 1982 and 1990. In 2005, a request for him was made by the government of Belgium which requested the UN's highest court to order Senegal, the asylum state, to extradite him, to stand trial in Brussels (BBC News, 2012). There was also the extradition case of Omar al-Bashir of Sudan, accused of genocide and mass killing which led to the death of over 300,000 people and generated two million refugees (Financial Times, 2015). On 17 May 1996, the South African authorities granted a warrant for the arrest of Robert John Hendrick, a staff of ABSA Bank Ltd., accused of financial fraud and theft, alleged to have occurred between November 1995 and March 1996. His extradition request was made in 1998, following the discovery of the theft after his exit from the bank and from his country to Scotland (Scottish Courts and Tribunals Report, 2005).

Following the 2007 to 2008 post election violence in Kenya in which 1,200 people were killed and tens of thousands of others were displaced internally, President Uhuru Muigai Kenyatta and ex-deputy president William Samoei Arap Ruto and some of their political allies in Kenya were accused of being the masterminds of the violence. A request was made by the International Criminal Court (ICC) to extradite Ruto to face prosecution, but in September 2013, his case was discharged for insufficient evidence. Essentially, too, was the case of Mr. Kenyatta who was accused alongside his allies but was dropped for the same reason (Alastair, 2016).

In March 2001, the UN Security Council Resolution 1343 imposed a smart sanction against ex-president Charles Taylor of Liberia. Taylor was accused of backing and arming the rebel groups in his country and in Sierra Leone. Besides, he was accused of running a despotic governance in Liberia plus his failure to take reasonable 
measures to punish criminals who perpetrated crimes against humanity; and being the mastermind behind the assassination attempt on the then Guinean President Lansana Conte on 19 January 2005 while he was the president of Liberia between 1997 to 2003. He was later arrested and held in UN prison in Freetown, Sierra Leone, while he awaited his extradition to The Hague in the Netherlands. He was later tried and sentenced to 50 years imprisonment (Lang, 2010; Ezeibe, 2011: Chilaka, 2014).

The impact of the present world system in Africa was also evident in the case of Chief James Onanefe Ibori, former Governor of Delta State, Nigeria. On 14 December 2010, he was extradited from the United Arab Emirates to the United Kingdom for fraud and money laundering. He was also accused by the Federal Government of Nigeria for misappropriation of public funds while he served as the Executive Governor of Delta State. The case today is regarded as the most celebrated resistor case in the history of Nigeria (PUNCH, Saturday 15, 2010: 6). On 15 July 2014, the alleged masterminds of Nyanya, Abuja Bus Terminal Twin bomb blasts, Aminu Sadiq Ogwuche, a member of the Boko Haram terrorist organisation was extradited from Sudan to Nigeria. The April 14, 2014 bomb blast was one of the most terrible terrorist attacks in Abuja, the capital city of Nigeria (Omonobi \& Ojeme, 2014). In 2011, Emmanuel Ekhator, a Nigerian citizen was extradited to the USA over the allegation of mail and wire fraud. He was later sentenced in September 2013 to a three-year jail term and ordered to pay back the sum of $\$ 11,092,028$ in restitution to his victim (Soni, 2013). The Ogun State of Nigeria's East District Senator in the Abuja National Assembly and Peoples Democratic Party (PDP) governorship candidate for the February 2019 general elections, Senator Buruji Kashamu, is likely to be extradited to the United States for alleged narcotic offence committed in the United States in 1994, following a fresh move by the Federal Government of Nigeria to extradite him to the United State of America. In fact, Kashamu has been battling with this case for some time now (ThisDay Live, 2018; Oladimeji, 2018). Another Nigerian, a former Minister of Petroleum Resources and a chieftain of the Peoples Democratic Party (PDP), Mrs. Diezeani Alison-Madueke may be extradited from the United Kingdom to Nigeria, following the move by the Government of Nigeria over several allegations of corruption, impropriety and looting of public funds leveled against her while in office as a minister of the Federal Republic (Premium Times Agency Report, 2018).

On 6 April 1999, Mr. Jerome Clement Bicamumpaka, former Minister of Foreign Affairs in Rwanda, was arrested and extradited from Cameroon to the International Criminal Tribunal for Rwanda (ICTR) in Arusha, Tanzania, for his involvement in the genocidal war and in the extermination of the Tutsi tribe and some of the moderate Hutus of Rwanda. Other co-defendants were Casimir Bizimungu, former Minister of Health; Justin Mugenzi, former Minister of Trade and Industries, and Prosper Mugiraneza, former Minister of the Civil Service (see Trial International, 2016). Other culprits extradited are Mr. Wenceslas Twagirayezu, alleged to have led a pro-Hutu militia in the north-west of the country against the Tutsi ethnic group. He was extradited from Denmark to the ICTR, and Emmanuel Mbarushimana who was sentenced to life imprisonment in 2007, three years after his extradition (BBC News Africa, 2018).

On 6 June 2017, the courts in South Africa issued an order for two suspects, Simbarashe Charuma and Prince Chindawande, who were wanted for the murder of their employer in the province of Limpopo. Both suspects fled to Zimbabwe, to avoid arrest and prosecution. In this case, both the asylum state, Zimbabwe, and the requesting state, South Africa, were hamstrung and could do nothing about the unfortunate and inevitable legal consequence since the accused persons had since been released from a Zimbabwean prison and were at large (Richard, 2018).

Essentially, too, is the recent extradition request by the South African authorities for a Zimbabwean Reginald Bernstein, an accountant by profession who was wanted for close to R11 million theft. The money was alleged to have been stolen from the Dainfern Gulf Estate and Country Club Homeowners' Association in Gauteng between 2009 and 2015 (Ndaba, 2018). The South African authorities, according to the United States Department News (2015), extradited six Nigerian nationals, Oladimeji Seun Ayetolan, Rasaq Aderoju Raheem, Olusegun Seyi Shonekan, Taofeeq Olamilekan Oyelade, Olufemi Obro Omoraka, and Anuoluwapo Segun Adegbemigum from South Africa to Gulfport, Mississippi, to face a nine count federal indictment in the Southern District of Mississippi, for alleged mail fraud, wire fraud, bank fraud and conspiracy to commit identity theft in an October 7, 2014 indictment (US Department News, 2015).

The recent extradition treaty signed by the South African authorities and the United Arab Emirates will see to the extradition of the Gupta brothers: Ajay, Atul and Rajesh, who fled to the United Arab Emirates city of Dubai earlier in 2018 as criminal investigation for their alleged involvement in corruption during the administration of the former president of South Africa, Jacob Zuma, who was considered to be a friend and ally to the brothers (Greg, 2018). There was also the extradition case of the honeymoon murder suspect, Shrien Dewani, from Bristol, over the death of his wife, Annis Dewani, who was shot as the couple travelled in a taxi on the outskirts of Cape Town in South Africa, in November 2010. In July 2013, Chief Magistrate Howard Riddle ruled at the Westminster Magistrate court that Mr. Dewani be extradited from United Kingdom to South Africa for trial (The Guardian News, 2014).

Apparently, the list of extradition scenarios and the cases above extrapolate the fact that the present world order has a remarkable impact or influence in the change of perception of what constitutes a crime and what does 
not, which subsequently led to the increase in extradition deals and the prosecution of fugitive offenders and criminals in Africa. In other words, the above listed cases of extradition in Africa are some selected cases among several others of the past and present.

\subsubsection{United Nations and Implementation of Extradition Laws in Africa}

It is imperative to recall that the end of the cold war has permitted and contributed to the progressive realization of Section 1 of the Article of the UN Charter which deals specifically with the achievement of international cooperation in resolving global economic, social and cultural problems or those with humanitarian character. It equally encouraged respect of human dignities and rights. The reawakening of the UN Security Council and the General Assembly is also of tremendous importance to the realization of the need for implementation of international extradition laws and respect for human rights and dignity to which the Africa Union (AU) has no option but to emulate. However, modern extradition treaty agreements seek to balance the rights of individuals, and to ensure that extradition practices are in tandem with the established international norms which were designed not only to protect the exercise of extradition but also to assure the fugitive offender of some degree of procedural fairness and essentially, preserve his fundamental right to fair hearing (Benteka \& Nash, 2003).

A typical example of the UN efforts in promoting extradition processes abound in the 1990 General Assembly approved model treaty on extradition which contains a lot of principles with the purpose of providing useful framework for states including those in Africa, in the negotiation and revision of bilateral agreements. A Revised Manual on the Model Treaty on Extradition and the Model Treaty on Mutual Assistance in Criminal Matters, 2004 were also approved. Notably, also, was the UN Convention against torture and inhuman or degrading treatment or punishment held in New York in December 10, 1984. Article 3 of the Convention specifically imposed on all state parties certain obligations with respect to extradition such as:

No state party shall expel, return or extradite a person to another state where there are substantial grounds for believing that the person will be in danger of being subjected to torture and for the purpose of determining whether there are such grounds (Article 3 of UN Convention against Torture, 1994).

The Convention directs competent authorities to take into account all relevant considerations in the state concerned, to ensure a consistent pattern in the prevention of gross or mass violations of human rights. A typical example is the replication of the position of the Convention in the African Union (AU) Commission on Human and Peoples' Rights (ACHPR) based in Banjul, Gambia. The ACHPR is a subsidiary of the AU, charged with the responsibility of promoting and protecting human and peoples' rights throughout the African continent. Its legal text lies with African Charter on Human and Peoples' Rights of 1987 with a Protocol adopted in 1998. The AU Charter also provides for the African Court on Human and Peoples' Rights, a regional court that ensures compliance with the African charter on human and peoples' rights by member states. Apart from these, there are two other African legal texts: the specific rights of African women and children (see African Charter on Human and Peoples' Rights, 1987). All of these provisions became more practicable with the emergence of the present world order which ushered in tremendous changes in our perception of what constitutes a crime and what does not; what is good and what is not, and the sub sequential increase in extradition agreements in Africa.

Notable, too, is the provision of UN Convention against illicit traffic in narcotic drugs and psychotropic substances of 1988. This provision played a remarkable impact in Africa's fight against trafficking in illicit substances. The convention made commendable efforts in establishing international treaty provisions against drug trafficking. In February 1990, the General Assembly's Seventeenth Special session devoted to international drug issues adopted a global programme of action to eradicate all forms of crimes relating to trafficking of illicit substances. It called for the strengthening of judicial and legal systems in the areas of law enforcement, drug trafficking, diversion of arms and explosives, and trafficking in illicit materials by rail, road, air and water (see UN Convention Against Illicit Traffic in Narcotic Drugs and Substances, 1988). Article 16 of the UN Convention against Corruption, 2003 made it essential for state parties, including those in Africa, to remove all forms of impediment to extradition provisions. This became so in order to deny those individuals or group of individuals or even organizations that finance, plan, support or commit terrorist acts which otherwise provide safe haven for terrorists, and to ensure that such persons are brought to justice. Other pertinent conventions set up for the implementation of extradition laws include the International Convention for the Suppression of the Financing of Terrorism of 1999; the International Convention for the Suppression of Terrorist Bombing, 1997; and the European Convention on Extradition (Ezeibe, 2011).

These Commissions on narcotic drugs, the international convention for suppression of terrorist financing and terrorist bombing, called for greater judicial cooperation among the nations of the world including African nations. Its mandate was to, as a matter of urgency, adopt laws and procedures that can facilitate criminal investigations. It also recommended ways to improve criminal justice system, as well as ways to use same more effectively, to fight illicit drug trafficking, terrorist financing and bombing. In essence, states are required to remove all manners of impediment, barrier or obstacle for extradition from drug related offences and other extraditable offences. Michael Byers (2000) has, however, argued that by way of UN Security Council (UNSC) Resolution 827 of 25 May 1993 
and Resolution 955 of November 1998, two international criminal tribunals were created to try individuals who were alleged to have committed grave violations of the provisions of the international humanitarian law in the former Yugoslavia, Rwanda and Sierra Leone. African states were the major beneficiaries of these tribunals since most African tyrants, dictators, leaders and private individuals who committed serious atrocities and war crimes were indicted, and some were tried by the tribunals and they included Charles Taylor of Liberia, Omar al-Bashir of Sudan, Hussein Habre of Chad, and Bicamumpaka, Bizimungu, Twagirayezu and Emmanuel Mbarushimana from Rwanda, etc. (Byer, 2000; Ezeibe, 2011).

In 2005, a joint UN-Sierra Leone tribunal was established to complement the effort of the United Nations, to deal with war crimes, particularly those committed during the Sierra Leonean civil war that began in 1996. By mid 2005, over thirteen persons from the Revolutionary United Front (RUF) led by Foday Sanko and his militia forces were indicted, and eleven others were held in the custody of the UN on charges of aiding the RUF. For almost a decade after the 1994 Rwandan genocide war, barely 70 individuals out of thousands involved in the massacres had been convicted by the UN-backed court that was established to judge justice. Despite this displeasing record, the creation of the International Criminal Court (ICC) located in The Hague with its ad-hoc sitting tribunals have kept politicians, tyrants, dictators, leaders and individuals in Africa on check. It has limited and prevented them from recklessly stoking ethnic conflict, genocide, trafficking in hard drugs and in humans, and from engaging in financial and mail frauds and other extraditable offences. Besides, it has advanced the prospect of increased extradition treaty arrangement and request in Africa. Unfortunately, corruption and other vices such as politics, ethnicity, tribal and social affiliations, etc. have hindered the progress recorded so far in Africa (Bowcott, 2014; Oluka, 2018).

\subsubsection{Possible Solutions to the Problems Associated with Extraditions in Africa}

The following are workable solutions and recommendations to the problems associated to extradition in Africa:

(i) As the new world order has contributed to the implementation of extradition treaties in Africa, it is imperative, as a matter of urgency, for African countries to have more bilateral agreements or treaties with one another particularly in areas where none existed before now. This will encourage formal and legal right to hand over alleged offenders from one country to another or from the state of asylum to the requesting state, and limit crime rates in Africa since none of the states will serve as safe haven for criminals.

(ii) African leaders generally must tread with caution in their relationship with the citizens and in implementation of their formulated policies especially those that directly affect the living standard of the citizens so as to avoid violent protests or riots that are often associated with the abuse of human rights.

(iii) Governments of African states must be careful not to recklessly grant asylum and presidential pardon to their family members or political associates. This may cause delay and barrier to extradition processes and requests. It may also serve as a reference point for people to commit crimes against humanity with impunity.

(iv) The UN Security Council, in its resolutions, should continue to assist African countries in establishing more permanent tribunals rather than ad-hoc courts in prosecuting criminals and fugitive offenders that have breached international humanitarian laws. As well, they should help to bring to book former dictators, tyrants and individuals who are yet to be indicted, arrested and prosecuted, as long as they live, because this will serve as deterrent to leaders who are in the saddle and the upcoming ones.

(v) The Government of states in Africa should continue to cooperate with other member countries of the UN and among themselves, to sustain the achievements recorded so far in the area of crime control through extradition agreements and exchange of wanted individuals and criminals.

\section{References}

Adishi, E., \& Oluka, N. L. (2018). The role of extradition treaties in crime management and combating terrorism. International Journal of Trend in Scientific Research and Development (IJTSRD), 2/2, 590-597

Ahmadinejad, M. (2012). Ahmadinajad calls for new world based on justice. Press TV, Archived at the Wayback Machine. [Online] Available: http://en.m.wikipedia.org/wiki/new-world-order-(politics) (May 26, 2012)

Akwen, G. T. (2011). Theories of international relations: An introductory text. Germany, Latvia: Lambert Academic Publishing, Chapter 5, pp. $104-119$.

Alastair, L. (2016). Kenya's William Ruto's case dismissed by ICC. BBC News Africa. [Online] Available: http://www.bbc.co.uk/news/world-africa-35965760 (April 5, 2016)

Ansari, S. (2004). System Theory and Management Control: Teaching Notes. [Online] Available: https://faculty.darden.virgina.edu $>$ ansaris/ (January 2, 2004)

Bassiouni, M. C. (2001). International Criminal Law in the Age of Globalization, in Essays in Honor of Antonio Cassese. Cassese's International Criminal Law, Oxford University Press. [Online] Available 
https:/global.oup.com/academic/product/casseses-international-criminal-law9780199694921 ?cc $=$ ng\&lang $=$ en \&

Bassiouni, M. C. (1974). International Extradition and World Public Order. The Netherlands, Leyden: Sijthoff Publishing, p. 630.

BBC News, (2001). Blair pushes for new world order. [Online] Available: http://en.m.wikipedia.org/wiki/newworld-order-(politics). (October 12, 2001)

BBC News, (2002). Blair returns to new world order. [Online] Available: http://en.m.wikipedia.org/new-worldorder-(politics). (January 4, 2001)

BBC News, (2012). Hissene Habre: Belgian extradition case opens at ICJ. [Online] Available: http://www.bbc.co.uk/news/world-africa-17337668. (March 12, 2012)

BBC Africa, (2018). Rwandan genocide suspect extradited from Denmark. [Online] Available: http://www.bbc.com/news/world-africa-46529332. (December 11, 2018)

Bentekas, I. \& Nash, S. (2003). International Criminal Law: 181 (2nd ed.). London: Routledge-Cavendish London.

Boston College, (2015). Maintained by Information Technology Services. [Online] Available: http://www.bc.edulbc.org. (April 30, 2015)

Bowcott, O. (2014). Legal affairs correspondent. [Online] Available: http://www.theguardian.com/world/2014/apr/02/rwanda-genocide-fight-justice. (April 2, 2014)

Brent, S. (1991). Buch's talk of new world order: Foreign policy tool or mere slogan? Washington Post. [Online] Available: https://en.m.wikiquote.org/wiki/new-world-order-(poliyics). (May 26, 1991)

Byers, M. (2000). The Role of Law in International Politics. London: Oxford University Press.

Chilaka, F. C. (2014). United States of American-Nigeria Relations and the Politics of Charles Taylor's Asylum. An Unpublished Thesis submitted to the Department of Political Science, University of Nigeria, Nsukka. Virtual Library [Online] Available: http://www.unn.edu.ng/publications/files/CHILAKA\%20FRANCIS\%20CHIGOZIE.pdf

Ezeibe, P. I. (2011). Globalization and extradition treaties: A case of Charles Taylor. A Dissertation Submitted to the Department of Political Science and Administrative Studies, University of Port Harcourt, Choba, Nigeria. September, 2011.

Daddis, J. L. (1991). Toward the post-cold world. Foreign Affairs, Spring 1991. [Online] Available: https://en/m/wikiquote.org/wiki/new-world-order-(politics).

Glahn, V. G. (1970). Law among nations: An Introduction to public international law (2nd Ed.). London: Macmillan.

Greg, N. (2018). Running out of place to hide: South Africa-UAE treaty opens door for Guptas extradition. Daily Maverick. [Online] Available: https://www.dailymarverick.co.za/article/2018-09-27-south-africa-uaetreaty-opens-door-for-guptas-still-hypothetical-extradition. (September 27, 2018)

Gorbachev, M. (1988). Speech to the United Nations General Assembly. [Online] Available: https://en.m.wikiquote.org/wiki/new-world-order-(politics) (December 7, 1988)

Grice, A. (2008). UN transformation proposed to create new world order. London: The Independent News [Online] Available: https://en.m.wikipedia.org/wiki/new-world-order (politics) (January 21, 1988)

International Center for Transitional Justice, (2009). [Online] Available: https://en.m.wikipedia.org/wiki/yugoslavia-war (January 1, 2009)

International Criminal Court (ICC), (2013). Kenyatta Case. [Online] Available: https://www.icc.cpi-int/kenyatta (September - October, 2011).

Kinze, S. (2008). US must share power in new world order, says Turkey's controversial president. The Guardian. [Online] Available: https://en'm'wikipedia.org/wiki/new-world-order-(politics) (August 6, 2008)

Lang, L. (2010). The Special Court for Sierra Leone: Media Coverage of Charles Taylor. University of California, Berkeley War Crime Studies Centre. [Online] Available: http://www.warcrimescenter.berkeley.edu

Mahajan, V. D. (1988). Political Theory. New Delhi: S. Chand and Company Ltd. In Oromaregheke, B. \& Oluka, N. L. (2016) Theory of International Relations. Benin City, Nigeria: Allen Publication (Chapter 3)

Martins, A. (2003). The palace of the end: The Guardian. [Online] Available: https://en.m.wikipedia.org/wiki/newworld-order-(politics). (March 4, 2003)

McHam, M. (1998). All's well that ends well: A pragmatic look at international criminal extradition. Journal of International Law, 20, 419-450.

Motsoko, P. (2015). The ICC is now an instrument of imperialism. Pambazuka News: Voices for Freedom and Justice. [Online] Available: https://www.pambazuka.org/governance/icc-now-instrument-imperialism. (25 June 2015)

Ndaba, V. (2018). 'SA wants Zimbabwean man extradited to stand trial in R11- million theft case. Times Live. [Online] Available: https:/www.timeslive.co.za/news/south-africa/2018-08-06-wanted-sa-man-fightsextradtion/ (August 7, 2018)

Oladimeji, R. (2018). Kashamu files fresh suit to stop extradition. PUNCH News. [Online] Available: 
https://punchng.com/kashamu.com/kashamufiles-fresh-suit-to-stop-extradition/ (November 11, 2018)

Oluka, N. L. (2018). Politics and extradition treaty: A study of Charles Taylor's extradition. An Unpublished Dissertation Submitted to the Post Graduate School, Department of Political Science, Delta State University, Abraka, Nigeria.

Omonobi, K. \& Ojeme, V. (2014). Ogwuche: April 14 Nyanya bombing suspect extradited to Nigeria. Vanguard Newspaper, 28, 8 (Wednesday July, 2014)

Onyekpe, J. G. N. (2001). Globalization and liberalization of the world economy. Akoka-Bariga, Lagos: Panaiaf Press. Cited in Oluka, N. L. (2018) Politics and extradition treaties: A study of Charles Taylor's extradition. An Unpublished Dissertation Submitted to the Post Graduate School, Department of Political Science, Delta State University, Abraka, Nigeria.

Premium Times Agency Report (2018). EFCC confirms moves to extradite Diezani Alison-Madueke. C http://www.premiumtimesng.com/news/headlines/295146-efcc-confirm-moves-to-extradite-diezani-alisonmadueke.html (November 11, 2018)

Prevent Genocide International, (2001): Extradition and transfer of persons suspected of genocide and other international crimes organized by Global Region. [Online] Available: http://www.preventgenocide.org/punish/extradition. (June 30, 2001)

Rebane, K. I. (1995). Extradition and individual rights: The need for an international criminal court to safeguard individual rights. Fordham University School of Law International Journal, 19/4, 1636 - 1683.

Richard, C. (2018). Southern Africa: Governments' extradition inaction sees suspects walk free. AllAfrica. [Online] Available: https://allafrica.com/stories/201805021104.html (2 May 2018).

Robert, H. Jackson Center (2001). The influence of the Nuremberg trial on international criminal law, executive summary. [Online] Available: http://www.robertjackson.org/speech-and-writing/the-influenve-of-thenuremberg-trial-on-international-criminal-law

Robyn, Z. T. (2007). The impact of the bill of right on extradition. Nelson Mandela Metropolitan University, South Africa. (Online) Available: http://hdl.handle.net/10948/830

Roth, K. (2014). African attacks the international criminal court: The New York review of books. [Online] Available: www.hrw.org/news/2014/01/14/africa-attacks-international-criminal-court (January 14, 2014)

Sadoff, A. D. (2016). Bringing international fugitives to justice: Extradition and its alternatives. [Online] Available: https://en.m.wil

Shaw, M. N. (1996). International Law (5th ed.). Cambridge: Cambridge University Press, Chapter 12. [Online] http://9jalegal.com.ng/downloads/Cases/International\%20Law/Shaw\%20-\%20International\%20Law\%205th $\% 20 \% 20$ edition.pdf

Scottish Courts and Tribunals (2005). Extradition request in respect of Robert John Headrick. [Online] Available: www.scotcourts.gov.uk/search-judgements/judgement?id=d4918aa6-8980-69d2-b500-ff000d74aa7. (October 27, 2005).

Soni, D. (2013). How a Nigerian Jailed in US Stole $\$ 11 \mathrm{~m}$. Vanguard News. [Online] Available: www.vanguardagr.com/2013/09/how-nigerian-jailed-in-us-stole-11m. (September 12, 2013)

Strobe, T. (1991). Post-victory blues: Foreign affairs. [Online] Available: https://en/m/wikquote.org/wiki/newsworld-order-(politics). (December 1991 to January 1992)

The United States Department of Justice, Home Office of Public Affairs (2015). Six Nigerian nationals extradited from South Africa to Mississippi to face fraud charges. [Online] Available: https://www..justice.gov/opa/pr/six-nigerian-nationals-extradition-south-africa-mississippi-face-fraudcharges (July 13, 2015).

The Guardian News, (2014). Shrien Dewani loses high court fight against extradition to South Africa. [Online] Available: https:/www.theguardian.com/world/2014/jan/31/shrien-dewani-high-court-extradition-southafrica. (January 31, 2014).

ThisDay Live, (2018). Senator Buruji Kashamu's Unending Battles. [Online] Available: www.thisdaylive.com/idex.php/2018/11/11/senator-buruji-kashamus-unending-battle/?amp. (November 11, 2018).

Trial International. (2016). Jerome Bicamunpaka Facts. [Online] Available: https://trialinternational.org/latestpost/jerom-bicamumpaka/ (June 7, 2016)

United Nations Office on Drugs and Crime (UNODC), (2016). Cases and materials on extradition in Nigeria. Country Office, Abuja.

\section{Official Documents:}

African Charter on Human and Peoples' Rights, (1986). [Online] Available: https://ihrda.org/2011/06/african.charter-turns-30-time-to-celebrate-time-reflect. Also [Online] Available: www.achpr.org/instruments/achpr/ (June 6, 1986)

Article 1 of UN Convention on Human Rights, (1994). 
Article 3 of UN Convention against Torture, (1994).

Nigerian law intellectual property watch incorporated (NLIP): Extradition treaty between the government of the federal republic of Nigeria and the government of the republic of South Africa (ratification and enforcement) Act 2002. [Online] Available: www.nlip.com/etradition-treaty-government-federal-nigeria-governmentsouth-africa/

Model Treaty on Extradition, (1990). United Nations Assembly Resolution 45/116. [Online] Available: https://www.un.org/documents/ga/res/45/e45r116.htm. (December 14, 1990)

UN Convention against illicit traffic in narcotic drugs and psychotropic substances, Charter VI, [Online] Available: https://treaties.un.org/Pages/ViewDetails.aspx? (Vienna 20 December, 1988)

UN universal declaration on human rights (1948). [Online] Available: www.un.org/en/universal-declarationhuman-rights/ (December 10, 1948)

US legal definition copyright (1997-2016). [Online] Available: http://definition.uslegal.com/d/doublecriminalitylus/legal (1997-2016).

United States code (U.S.C.) 18.31.18. (1948). Frauds and swindles. [Online] Available: https://www.law.cornell.edu/uscode/text/1841 (June 25, 1948) 